\title{
Analysis of Vocational High School Chemical Teaching Material on Atomic Structure Materials Based National Education Standard
}

\author{
Frensi Hasanah \\ Magister of Chemistry Education: \\ Postgraduate School \\ Universitas Negeri Medan \\ Medan, Indonesia \\ frensihasanah@gmail.com
}

\author{
Simson Tarigan \\ Departement of Chemistry Education \\ Universitas Negeri Medan \\ Medan, Indonesia
}

\author{
Retno Dwi Suyanti \\ Departement of Chemistry Education \\ Universitas Negeri Medan \\ Medan, Indonesia
}

\begin{abstract}
One effort to improve the quality of education in Indonesia was to develop teaching materials that are not yet in accordance with the national education standards. This study aims to analyze the suitability of teaching materials based on national education standard. This research was part of development research that uses quantitative and qualitative. The instrument of this study uses the feasibility assessment sheet of teaching materials in accordance with the national education standards. The research sample was conducted at the Tanjung Pura 1 State Vocational High School. There were three aspects of assessment of this book, namely the feasibility of content, the feasibility of language, and the feasibility of presentation using the type of linkert scale with a score of $1-4$, with criteria: 4 = very good; 3 = good; 2 = not good; $1=$ bad. The analysis used was descriptive analysis which was done by calculating the percentage value from the aspect of content, language and presentation. The results of the analysis of the quality of chemical teaching materials based on the national education standard body. 1) the feasibility of the contents of book A 2,4 and book $B 2,9,2$ ) the feasibility of language book $A$ 2,5 and book $B$ 2,6 and 3) the feasibility of presenting book $A 2,7$ and book $B$ 2,4. After development 1) the feasibility of the contents of book $3,7,2$ ) the feasibility of language book 3,4 and 3 ) the feasibility of presenting book 3,7 .
\end{abstract}

Keywords- Analysis; National education standards; content eligibility; language feasibility; feasibility of presentation

\section{INTRODUCTION}

Learning was a condition deliberately designed to create an atmosphere of learning that provides an opportunity for students to build their own knowledge. Currently the Curriculum is the 2013 curriculum, which has a basic view where students are subjects who have the ability to actively seek, process, construct, and use their knowledge [1]. Learning is one of factors that may determine the students' learning results [2], so that learning innovations should always be made. Meanwhile that the learning system at school tending to be based on behaviorism becomes one of factors raising the conflict phenomenon at school environment [3]. Chemistry includes chemical knowledge in the form of facts, theories, principles, and laws based on scientists' findings and scientific work [4]. Chemistry is the study of the structure of matter, and the changes experienced by matter [5]. Chemistry was closely related to the scientific approach, because chemistry is inseparable from the scientific process that underlies the emergence of a scientific approach. This is in accordance with the opinion of The College Board which states that scientific shortcuts will support the direct involvement of students with chemical phenomena, which means that in studying chemistry is needed a scientific approach that includes the process of solving problems and critical thinking so that students really understand the chemical phenomena [6]. The Colege Board. 2012. AP Chemistry Guided-Inquiry Experiments: Applying the Science Practice (Teacher Manual). New York: The College Board. "Science teachers should use updated methods and techniques in order to make the learning more meaningful by using the scientific language in a comfortable way to make subjects and concepts more understandable [7]

The chemistry teachers ought to know the procedures for constructing alternative instructional materials with which they can help their students to visualize whatever topic they want to teach. Dike in Omiko [8] noted that, if instructional materials are to be improvised, emphasis should be laid on using cheap and locally available materials. A chemistry teacher must be conversant with the types, characteristics and advantages of instructional materials before he/she could improvise. Omiko listed the benefits derived from the use of improvised instructional materials to include; (a) It makes students to participate in creative and analytical thinking when they are involved in making those needed instruments (b) concepts taught using improvised materials become clearer to the students because those concepts are learnt through playlike activities (c) It encourages a systematic integration of a variety of resources in a teaching-learning experiences. (d) Being actively involved in improvisation, the working principles are learnt and in this way the students acquire problem solving skills, manipulative skills, scientific attitude and knowledge needed in solving the daily scientific and technological problems [9].

Teaching material was one of the main factors in the learning process. Although the teacher can explain the material clearly, it will be incomplete if no lesson material was 
used [10]. Very effective teaching material used as a learning medium because it functions as a communication tool to bring accurate information from learning resources to learners. Using good teaching materials will perceive the competence of competency because it functions as a good, objective teacher, has truth and is relevant [11]. Thus teaching material as an educational medium was very necessary in learning because it can explain various difficult phenomena, including abstract concepts, into realistic knowledge.

\section{METHOD}

This research was conducted at vocational high School 1 Tanjung Pura in Langkat. This development research model uses a model Analysis - Design-Development-ImplementationEvaluation (ADDIE). This research is part of the research and development at this stage Analysis, Design, and development.

The population in this study were all teachers who taught at Vocational High School. The sample in this study was 2 teachers teaching chemistry at Vocational High School.

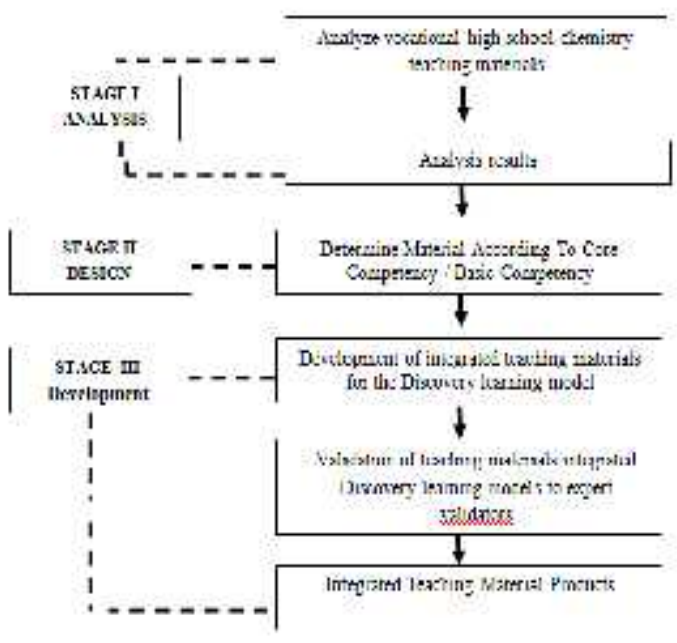

Fig I. Research Design

\section{RESULT AND DISCUSSION}

In this research, the development of teaching materials on atomic structure material. Before developing teaching materials, first, analysis of student chemistry books is used by vocational high school students. The questionnaire used in analyzing student handbooks was developed using the national education standards questionnaire. The questionnaire consisted of 3 criteria for content eligibility, language and graphics. In each eligibility criteria, there are aspects contained in it. These aspects can be seen in TABLE I. Before being used, the questionnaire instrument was validated by expert lecturers. This analysis aims to determine the level of eligibility of student books and teaching materials that have been developed. Eligibility criteria for student books and teaching materials were presented in TABLE II.
TABLE I. NATIONAL EDUCATION STANDARDS ASPECTS

\begin{tabular}{|l|l|}
\hline \multicolumn{1}{|c|}{ Eligibility } & \multicolumn{1}{|c|}{ Aspect } \\
\hline Content & $\begin{array}{l}\text { (1) Material coverage, (2) Material accuracy, } \\
\text { (3) Update, (4) Compliance with laws and } \\
\text { regulations }\end{array}$ \\
\hline Presentation & $\begin{array}{l}\text { (1) Presentation techniques, (2) Supporting } \\
\text { presentation of material, (3) Presentation of } \\
\text { Learning (Discovery Learning), (4) } \\
\text { Completeness of presentation }\end{array}$ \\
\hline Language & $\begin{array}{l}\text { (1) Conformity with the level of thought } \\
\text { development of students, (2) Readability, (3) }\end{array}$ \\
Ability to motivate, (4) Accuracy, (5) \\
Coherence and wrinkling of thought flow, (6) \\
Conformity with Indonesian language rules, \\
(7) Use of terms and symbol
\end{tabular}

TABLE II. ELIGIBILITY CRITERIA

\begin{tabular}{|c|c|}
\hline Average & Eligibility Criteria \\
\hline $3,26-4,00$ & Very Feasible \\
\hline $2,51-3,25$ & Feasible \\
\hline $1,76-2,50$ & Less Feasible \\
\hline $1,00-1,75$ & Not Feasible \\
\hline
\end{tabular}

\section{A. Analysis of the Student book}

Based on the results of the assessment sheet, descriptive analysis of the book can be analyzed and the following results are obtained, the feasibility of the contents 2,4 Book A, and 2,9 Book B, the language feasibility 2,5 Book A, and 2,6 Book $\mathrm{B}$, and the feasibility of presenting 2,7 Book A, and 2,4 Book B.

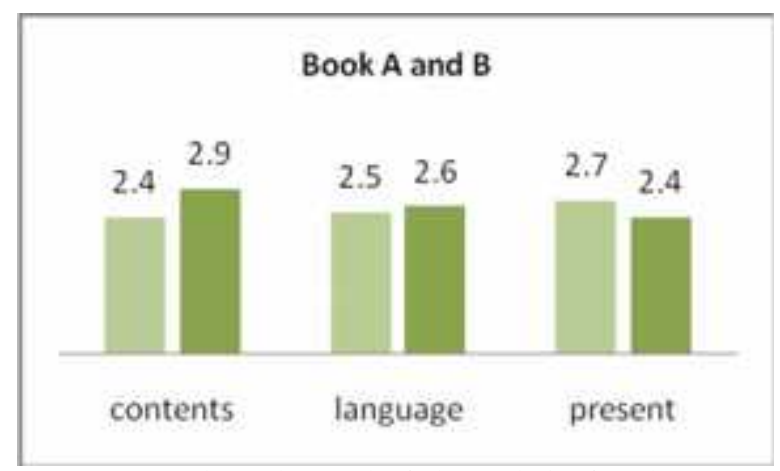

Fig 2. The Result of The Analysis of Books

\section{B. Development of Book}

After being developed, researchers conducted a standard test again using the same questionnaire. The results of the eligibility test the national education standards on atomic material by expert teachers obtained the value of the contents eligibility was the feasibility of the contents 3.7 , the language feasibility 3.4 , and the feasibility of presenting 3.7. 


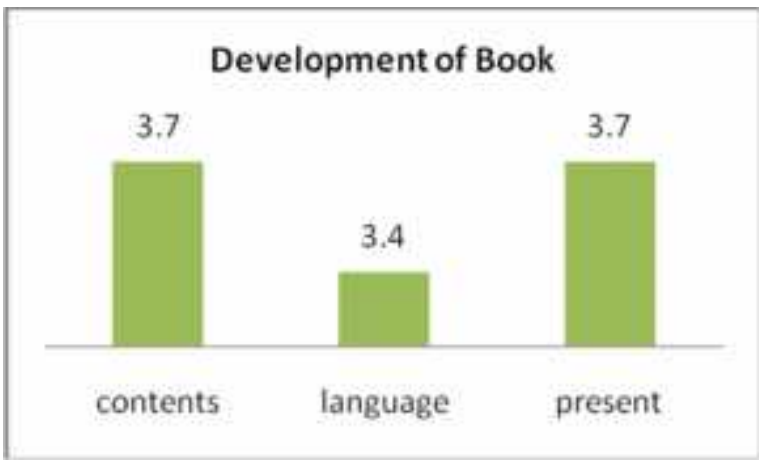

Fig 3. The Result of The Development of Book

\section{CONCLUSION}

Based on the results of data processing, it was concluded that the analysis of vocational high school chemical teaching material on atomic structure materials based national education standard and was suitable for use.

\section{REFERENCES}

[1] Ellizar. E, H. Hardeli, S. Beltris, and R. Suharni, "Development of Scientific Approach Based on Discovery Learning Module," IOP Conf. Series: Materials Science and Engineering, 335, 2018.

[2] Lim. D. H, Morris, M. L, "Learner and Instructional Factors Influencing Learning Outcomes within a Blended Learning Environment" Educational Technology \& Society, vol 12, pp 282-293, 2009.

[3] In'am. Akhsanul, Siti. Hajar, "Learning Geometry through Discovery Learning Using a Scientific Approach," International Journal of Instruction, vol. 10, pp. 55 - 70, January 2017.

[4] Khaerul Azmy1. Moh, Agus. A Purwoko, Saprizal. Hadisaputra, "The Development Of Chemistry Teaching Materials In The Form Of HandoutsBased (PBL)In Class XI IPA Madrasah Aliyah (Ma) Kediri District," IOSR Journal of Research \& Method in Education (IOSRJRME), vol. 8, pp 71-73, May-june 2018.

[5] Adiga, usha, Sachidananda, "Review Article Problem Based Learning. International Journal of Current Research," vol. 7, pp. 7181-17187, 2015

[6] Carera. Inova and Dasna. I wayan, "Pengembangan bahan ajar kimia rintisan sma bertaraf Internasional kelas xi materi laju reaksi" Jurnal Pendidikan, vol. 13, pp. 1-12, 2012

[7] Aydın. Abdullah, Cahit. Aytekin, "Teaching Materials Development and Meeting the Needs of the Subject: A Sample Application," International Education Studies, vol. 11, 2018

[8] Omiko, A, "Impact of instructional scaffolding on students' achievement in chemistry in secondary schools in Ebonyi state of Nigeria," International Journal of Education, Learning and Development (IJELD) www.eajournals.org, vol. 3. Pp. 74-83, 2015.

[9] Omiko, A, "Investigating The Availability And The Extent Of Use Of Instructional Materials By Secondary School Chemistry Teachers In Nigeria," International Journal of Education, Learning and Development, vol. 4, pp. 1-11, April 2016.

[10] Ratnawati,et all., kontribusi pedidikan karakter dan lingkungan keluarga terhadap soft skill siswa SMK, Jurnal keguruan dan ilmu tarbiah. 2013

[11] Zevenbergen, R., Dole, S., \& Wright, R.J. 2004. Teaching Mathematics in Primary Schools. Sidney: Allen and Unwin. 